(9)

\title{
操作の仕方と凸点の高さが 携帯電話の操作性に及ぼす影響の関係
}

\author{
${\text { 豊田航 }{ }^{1} \text {, 土井幸輝 }}^{2}$, 藤本浩志 ${ }^{1}$ \\ ${ }^{1}$ 早稲田大学, ${ }^{2}$ 国立特別支援教育総合研究所
}

要旨 本研究では，視機能が低下した高齢者及び視覚障害者における消費生活製品の操作性向上 に寄与する凸点の高さの条件を明らかにすることを目指し，携帯電話における操作の仕方と凸点 の高さがその操作性に及ぼす影響の関係を評価することを目的とした，本実験では，中途失明の 一般ユーザーを想定して，手元を遮蔽した晴眼若年者と晴眼高齢者に対して，高さが異なる凸点 が 5 番キーに付された携带電話を，人差し指による両手操作をさせる実験を行った。さらに，本 実験で新たに収集した人差し指による両手操作の結果と, 先行研究の親指による片手操作の結果 を比較することで，各操作の仕方における凸点の高さが携帯電話の操作性に及ぼす影響の違いを 分析した，その結果，人差し指と親指の各操作に扔いて，若年者と高齢者のいずれも，凸点の高 さが $0.3[\mathrm{~mm}]$ の条件は，それよりも高さが低い条件と比べて早く正確に操作した，一方，親指 による片手操作では，凸点が $0.3[\mathrm{~mm}]$ よりも高くなるにつれて操作時間とエラー率が増加した が, 人差し指による両手操作ではこうした凸点の高さの増加に伴う操作時間とエラー率の増加が 認められなかった。これらの結果の相違は, 両手操作と片手操作における手指の動作の違いに起 因すると考えられる.

キーワード：凸記号, アクセシブルデザイン, 操作性, 携带電話, 標準

\section{1.はじめに}

近年，世界各国で高齢者人口比が増大しており， 身体機能が低下した高齢者や障害者に配慮した社会 基盤の構築が, 国の重要な政策の一つに位置付けら れている。とりわけ，視覚障害者は，公共空間の移 動や情報入手等のごく日常的な生活動作に制限を受 けることから, 人権保障という観点から, ニーズに 配慮した生活環境, 消費生活製品等の普及が必要で
ある。この実現に向けて, 我が国では, 高齢者・障 害者への配慮を目的とした設計理念であるアクセシ ブルデザインに関して，標準化が推進されている. アクセシブルデザインとは,「何らかの機能に制限 のある人に焦点を合わせ，これまでの設計をそのよ うな人々のニーズに合わせて拡張することによって， 製品や建物やサービスをそのまま利用できる潜在顧 客数を最大限まで増やそうとする設計」と定義され ている1)。これまでに視覚障害に関するアクセシブ ルデザインの標準としては, 公共施設・設備の利 
104 バイオメカニズム 21

用・操作方法などの情報伝達手段として用いる点字 の表示原則及び点字表示方法に関する JIS（T 0921 ${ }^{2)}$ や触知案内図の情報内容及び形状並びにそ の表示方法に関する JIS（T 0922）等の数多くの標 準が制定されている。また，アクセシブルデザイン の基本規格として, 2001 年に国際標準化機構（ISO） は，高齢者及び障害のある人々のニーズに対応した 標準作成配慮指針（ISO/IEC Guide 71) ${ }^{4)}$ を制定し た。これにより，ISO/IEC 加盟国が自国内で標準 を制定する際に配慮すべき指針が定められた。高齢 化の進展が著しい我が国は, ISO/IEC Guide 71 の 制定を議長国として提案した立場にあるが，その提 案に先立ち, 幾つかの高齢者・障害者配慮設計指針 が財団法人日本規格協会によって既に標準化されて いた。

その一つが 2000 年に制定された凸記号表示に関 する JIS (S 0011) ${ }^{5)}$ である。 凸記号とは, 消費生活 製品の操作部に触覚上の手掛かりとして付す突起物 であり，高齢者や視覚障害者を含めた全てのユーザ 一の製品に対するアクセシビリティ向上を目的とし て付される。これまで多くの視覚障害者は, 製品の 購入後に操作キーに点字等を貼付することで, 晴眼 者と同じ製品を利用できるように工夫をしてきた。 しかし，上述の凸記号に関する JIS (S 0011) ${ }^{5)}$ の制 定によって様々な製品に凸記号が付されるようにな ると, 視覚障害者は製品の購入直後から簡便に晴眼 者と共用できるようになった。 また, 晴眼者にとっ ても視覚に頼り難い状況で, 触覚上の手がかりとし て有用であり，一般ユーザーにとって広く有効なア クセシブルデザインである。一方，凸記号に関する JIS (S 0011) ${ }^{5)}$ が推奨する凸記号の寸法は, 凸記号 を触った際の主観的な印象を調べたモニター調査 ${ }^{6)}$ が参考にされた、しかし，現状では凸記号の寸法と 消費生活製品の操作性との関係を示す客観的データ が必ずしも十分ではないことから，凸記号の推奨寸 法に関する基礎研究が必要とされている。特に, 現 在では日本国内のみならず, 国際的な整合性が重要 であるとして凸記号の国際標準化に向けた取り組み が進められており ${ }^{7)}$, 新規国際規格 (IS) を検討す る過程においては，標準に扔ける推奨寸法が，一般
ユーザーにとって広く有用であることを示した定量 的デー夕が必要である ${ }^{8)}$.

そのため筆者らは, 先行研究9)に扔いて, 凸記号 を付す一般的な消費生活製品である携帯電話に着目 し，凸記号の一種である凸点（凸状の丸い点）の高 さが, 親指による片手操作時の携帯電話の操作性に 及ぼす影響を評価した。実験の結果, 凸点が 5 番キ 一に付されていると, 凸点が付されていない場合と 比較して, 携带電話の操作性が向上することが明ら かとなり, 凸点の有効性が定量的に示された，さら に，凸点の高さがある範囲を超えて高くなると，携 帯電話の操作性が低下する傾向が確認できたことか ら，凸点は高ければ高いほど良いというわけではな く, 適切な範囲が存在することが明らかとなった。 これらの知見は, 企業が携带電話等のモバイル機器 の操作部に凸記号を付す際の参考データとして有用 である，他方，携帯電話の操作の仕方としては，本 体を保持した手の親指で操作する方法が多いが, 両 手を使って操作する方法も多い. 大河内らが視覚障 害者ユーザーを対象に実施した携帯電話・PHS の 利用実態調査 ${ }^{10)}$ では，片手で携帯電話を保持し，も う一方の手の人差し指で操作する視覚障害者は調査 対象者全体の 69[\%]であり，親指が24[\%]であっ た。これらを合わせて全体の 93[\%]を占めている ことから, 多くのユーザーは, いずれかの操作の仕 方に該当する可能性がある。 また, 筆者らは共同研 究を行っている日本点字図書館を利用する視覚障害 者にヒアリングをしたところ，人差し指により両手 操作をするといった意見が多く確認された。そのた め, 人差し指による両手操作時の凸点の高さが携帯 電話の操作性に及ぼす影響を明らかにすることは, 重要な課題の一つである。 また, 人差し指による両

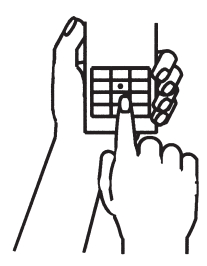

（a）人差し指による両手操作

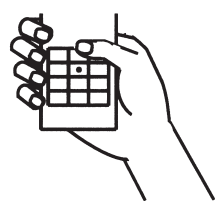

（b）親指による片手操作
図 1 本研究において評価の対象とする操作の仕方 
（9）操作の仕方と凸点の高さが携帯電話の操作性に及ぼす影響の関係 105

手操作と，親指による片手操作では，操作の姿勢が 異なる，そのため，こうした操作の仕方の違いによ って, 凸点の高さが携帯電話の操作性に及ぼす影響 が異なる可能性がある.

そこで本研究では, 携帯電話の操作の仕方として, 人差し指による両手操作と親指による片手操作に着 目し (図 1 参照)，これらの操作の仕方と凸点の高 さが携帯電話の操作性に及ぼす影響の関係を評価す ることを目的とした，具体的には，中途失明の一般 ユーザーを想定して，手元を遮蔽した晴眼若年者と 晴眼高齢者に対して，高さが異なる凸点が 5 番キー に付された携帯電話を，両手人差し指により操作さ せる実験を新たに行った。そして、この新たに収集 した人差し指による両手操作の結果と, 先行研究9) で収集した親指による片手操作の結果を比較するこ とで，凸点の高さが人差し指と親指による各操作性 に及ぼす影響を評価した。

\section{2. 実験方法}

\section{1 実験装置}

凸点の高さが携帯電話の操作性に及ぼす影響を評 価するために, 2.3 節で述べる入力課題を行う際の 携带電話の操作を, 時系列データとして正確に記録 できる実験装置を製作した。実験装置の概念図を図 2 に示す，実験装置は，実験で参加者に操作させる 携带電話モックアップ, データロガー（株式会社キ ーエンス NR-500)，PCによって構成される。市場 で流通する携帯電話には，キー自体に凹凸がある機 種や各キーが離れている機種等があり，こうしたキ 一の形状やレイアウト等も触覚上の手がかりとなり, 操作性に影響を及ぼす可能性がある。即ち，テンキ

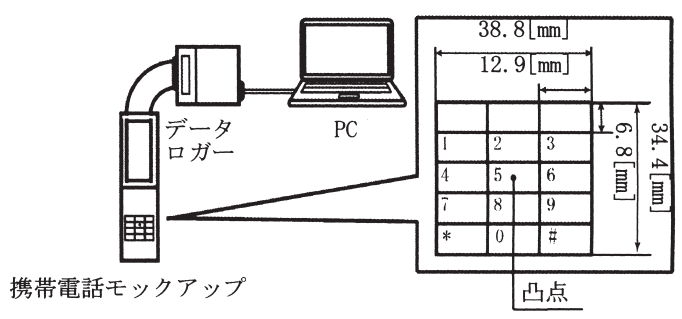

図 2 実験装置の概念図
一の特性による影響を排除しなければ，触知覚特性 に対する凸点の高さが携带電話の操作性に及ぼす影 響のみを評価することができない，そこで，本研究 では, テンキーの全てのキーが平坦であり, 隣り合 ったキー同士が近接している機種（シャープ株式会 社 Softbank 912SH）を使用することで, 凸点以外 の触知覚に関する影響を排除することとした。これ により, 触知覚特性の観点から, 携帯電話に付す凸 点の適切な高さを明らかにすることを可能とした。 なお，テンキーのクリック感は，当該機種の実物と 同様である。このテンキーの下に，フレキシブルプ リント基板で製作した電極パターンを挿入して, 各 キーの on-off 状態を電圧信号として計測できるよう にした。こうして携帯電話モックアップの操作は, データロガーを介して，PC上で時系列データとし て正確に記録できる。なお，本実験の実施前後と， 実験の休賏中には必ず動作確認を行い，正常に動作 することを確認した上で実験を実施した。

凸点を付すテンキーは同型のものを 5 個用意し， 各 5 番キーの中央にスクリーン印刷によって, 紫外 線硬化樹脂インクの凸点を形成した。 凸点は, 硬化 不良を起こさないように, 十分に露光して付した。 図 3 に凸点の基本設計を示す。凸点の高さは 0.0 (凸点なし)，0.1，0.3，0.5, $0.7[\mathrm{~mm}]$ の 5 条件と し，それぞれ直径 $1.0[\mathrm{~mm}]$ 程度とした。実験では, これらの高さが異なる凸点を付したテンキーを携帯 電話本体に付け替えることで, 凸点の高さのみを要 因とした携帯電話の操作性評価を可能とした。なお， 市場で流通している携帯電話には，テンキーに複数 の凸点を付した機種や，5番キーの端に凸点を付し た機種等がある、しかし，本実験では，凸記号表示

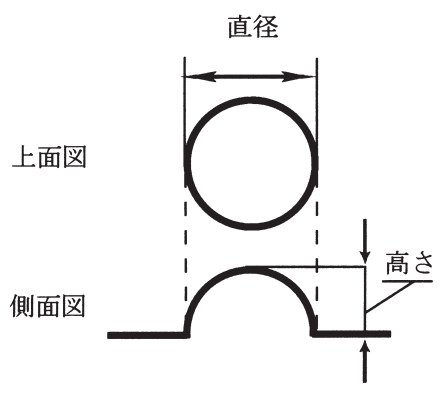

図 3 凸点の基本設計（出典：執筆者） 
106 バイオメカニズム 21

に関する JIS (S 0011) $)^{5)}$ において規定された凸点の 付し方であり，多くの機種によって採用されている 5 番キーの中央に付す方式によって評価することと した.

\section{2 実験参加者}

本実験では，高齢化の進展とともに増加が懸念さ れる中途失明者を想定し, 晴眼若年者 18 名（平均 21.1 歳 \pm 1.2 歳）及び晴眼高齢者 20 名（平均 64.2 歳 2.5 歳）の協力を得た。全ての参加者は, 携帯 電話の操作経験があり, テンキーの配列を把握して いた．また，少なくとも週に一回以上はメールや通 話, インターネットなどで携带電話のテンキーを操 作する機会があり，一年以上に亘る携帯電話の使用 歴があることを選定条件とした，さらに，携帯電話 の使用経験が全くない者や, 携帯電話を毎日一日中 操作している者等, 携帯電話の使用頻度が突出して 異なる参加者は除外した。なお，皮膚に外傷や関連 する既往歷がなく, 手指の機能に異常が認められな い参加者から協力を得た。

\section{3 手続き}

本実験では, 参加者が携帯電話の操作部を目視で きないように, カーテンで手元を遮蔽した状態で携 帯電話モックアップを持たせた。 そして, 入力課題 として，目の前に呈示した 0 から 9 までのランダム 順列のアラビア数字 50 個を操作させた. 課題の操 作が終了した後, 携帯電話の操作感に関して, 2.4 節で詳述する主観評価を回答させた。ここまでを 1 試行として，凸点の高さ 5 条件 $\times 4$ 試行の合計 20 試行を行った。 なお， 参加者には, 片手で携帯電話 を保持しながら，もう片方の手の人差し指を用いて, 携帯電話を操作するように指示した。操作に用いる 左右の手は, 参加者が操作しやすいように自由に選 定させ，最後まで同一側で実験を行った，また，入 力課題の表記に関しては, 参加者が入力している数 字を見失わないように，5列目及び 10 列目を赤い 文字にすることで配慮した。なお，凸点の影響を観 測するために，（1）一つの文字を入力するごとに， 5 番キー上に指を戻してから次のキーを入力するこ
と，（2）速さよりも正確さに配慮して操作すること， 以上を参加者に指示した。本試行の前には練習試行 を実施することで, 参加者が実験者の指示に従って 携帯電話を操作できることを確認した。 また, 参加 者の体調に注意して, 適宜休憩を取りながら行った 実験時間はおよそ 2 時間であった。

以上の全ての手続きは, 早稲田大学研究倫理審査 委員会の承認を得た。参加者に対しては, 実験を開 始する前に研究の詳細を説明し, 実験参加の同意を 得た.

\section{4 評価指標}

凸点の高さが携帯電話の操作性に及ぼす影響を評 価するための定量的な評価指標として，操作時間及 びエラー率を採用した，操作時間は，2.3 節で述べ た入力課題であるアラビア数字 50 個の操作に要し た時間とした．エラー率は, アラビア数字 50 個あ たりに発生したエラーの個数をパーセンタイルで算 出した値とした.

さらに, 副次的な評価指標として, 携帯電話の操 作感に関する 3 つの主観評価を採用した（表 1 参 照)。具体的には, 操作の確信度（1：確信なし〜 5 ：確信あり），5番キーの発見しやすさ（1：全く 発見できない〜 5 : 確実に発見できる)，5番キーを 押した際に指に感じた痛み（1：全く痛みを感じな い〜 5: 非常に痛みを感じる) とし，それぞれ 5 段 階の等間隔尺度で評価させた。これらの主観評価は， 親指による操作実験を行った先行研究年ににおいて, 操作時間とエラー率の結果に差が認められない場合 や，操作時間とエラー率では観測できない主観的な 操作しやすさを評価する有用な指標であったことか ら, 本研究においても採用した。 なお，操作の確信

表 15 段階の等間隔尺度による主観評価

\begin{tabular}{|c|c|}
\hline \multicolumn{2}{|l|}{ 操作の確信度 } \\
\hline $1:$ 確信なし & 〜 5:確信あり \\
\hline \multicolumn{2}{|l|}{ 5番キーの発見しやすさ } \\
\hline $1:$ 全く発見できない & 〜 5:確実に発見できる \\
\hline \multicolumn{2}{|c|}{ 5番キーを押した際に指に感じた痛み } \\
\hline 1:全く痛みを感じない & 〜 5:非常に痛みを感じる \\
\hline
\end{tabular}


（9）操作の仕方と凸点の高さが携帯電話の操作性に及ぼす影響の関係 107

度は, 入力課題を操作した際の確信の度合いと定義 し，本実験の中で参加者に対して「どれくらい自信 をもって携帯電話を操作できたのかを，入力課題を 操作した際の主観的な操作しやすさから判断して下 さい.」と指示した。

\section{5 評価方法}

本研究では, 人差し指で操作を行った際の実験結 果に関して，2.4 節で述べた評価指標ごとに， 凸点 の高さを要因とする対応のある一元配置分散分析及 びBonferroni 補正法による多重検定によって高さ の条件間における有意差を分析した。更に，人差し 指での操作結果と先行研究 ${ }^{9)}$ における親指での操作 結果の違いを比較し, 各指における凸点の高さの影 響を評価することとした。 なお，本研究では，操作 に用いる指の優劣や, 加齢効果の評価は目的ではな い. そのため, 操作に使用した指と, 年龄を要因と する分析は行わないこととした。

\section{3. 結果}

3.1 節では，本研究で実施した人差し指による両 手操作の結果を述べる。 3.2 節では, 先行研究 ${ }^{9)} に$ おける親指による片手操作の結果を引用し，本研究 における人差し指による両手操作との結果の違いを 評価する。

\section{1 本研究において新たに実施した人差し指 による両手操作の結果}

凸点の高さを要因とする対応のある一元配置分散
分析の結果, 若年者と高齢者のいずれにおいても, 全ての評価指標で凸点の高さの主効果が有意であっ た (表 2 参照). Bonferroni 補正法による高さの条 件間における有意差に関しては，3.1 節(1) から （6）において，括弧内に有意確率を示した。以下に, 各評価指標の結果を，具体的に述べる.

(1) 操作時間

図 4(a)より，若年者では，0.3[mm]に対して $0.1[\mathrm{~mm}], 0.1[\mathrm{~mm}]$ に対して $0.0[\mathrm{~mm}]$ は，操作時 間が有意に長かった $(\mathrm{p}<0.05)$. 高齢者では, 0.3
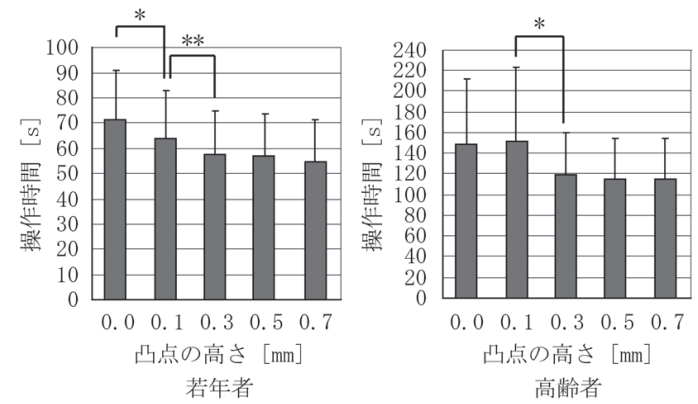

(a) 操作時間
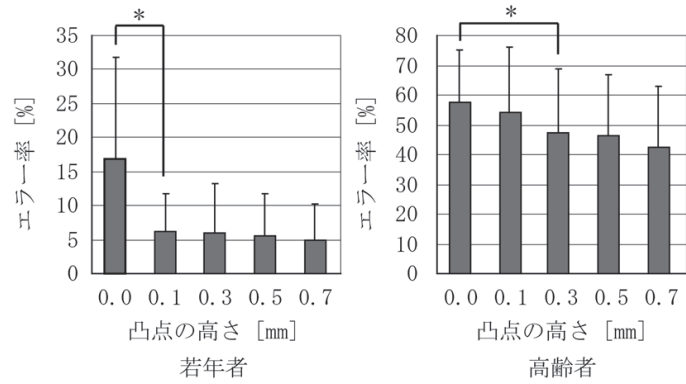

(b) エラー率

高齢者

$*: \mathrm{p}<0.05, * *: \mathrm{p}<0.01, * * *: \mathrm{p}<0.001$

図 4 人差し指による実験の結果

表 2 人差し指による実験の分散分析の結果 $\mathrm{F}(\mathrm{df})$

若年者 高齢者

操作時間

エラー率

操作の確信度

5番キーの発見しやすさ

5番キーを押した際に指に感じた痛み
$32.73(4,68) * * *$

12. $39(4,76) * * *$

$15.97(4,68) * * *$

$81.31(4,68) * * *$

$106.91(4,68) * * *$

$34.34(4,68) * * *$

$*: \mathrm{p}<0.05, * *: \mathrm{p}<0.01, * * *: \mathrm{p}<0.001$ 
108 バイオメカニズム 21

$[\mathrm{mm}]$ に対して $0.1[\mathrm{~mm}]$ は操作時間が有意に長か った（p<0.05）．若年者と高齢者ともに，0.3[mm] 以上の条件間では有意差が認められなかった。

(2) エラー率

図 4(b)より, 若年者では, $0.1[\mathrm{~mm}]$ に対して $0.0[\mathrm{~mm}]$ はエラー率が有意に高く $(\mathrm{p}<0.05), 0.1$ $[\mathrm{mm}]$ 以上の条件間では有意差が認められなかった 高齢者では， $0.3[\mathrm{~mm}]$ に対して $0.0[\mathrm{~mm}]$ はエラー 率が有意に高く $(\mathrm{p}<0.05), 0.3[\mathrm{~mm}]$ 以上の条件 間では有意差が認められなかった，若年者と高齢者 ともに, $0.0[\mathrm{~mm}]$ の時に最もエラー率が高かった.
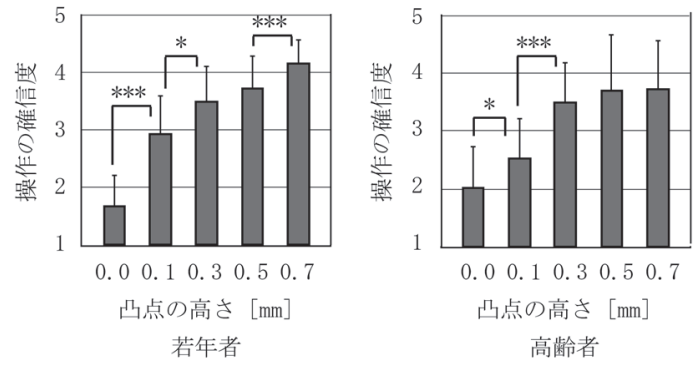

(a) 操作の確信度

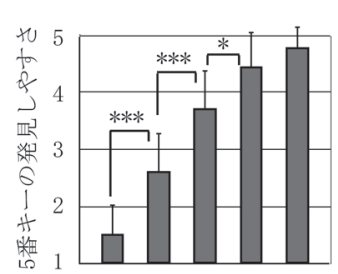

$\begin{array}{lllllll}0.0 & 0.1 & 0.3 & 0.5 & 0.7\end{array}$

凸点の高さ $[\mathrm{mm}]$

若年者

（b）5番キーの発見しやすさ

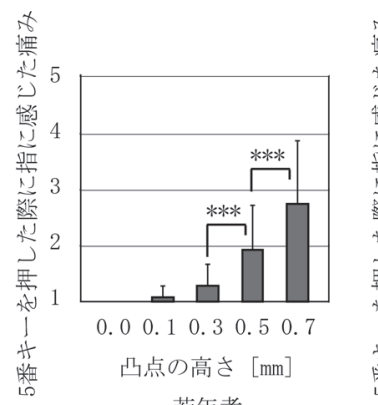

若年者

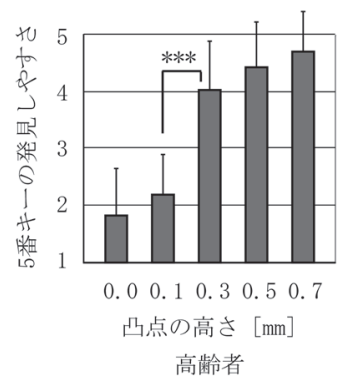

高齢者

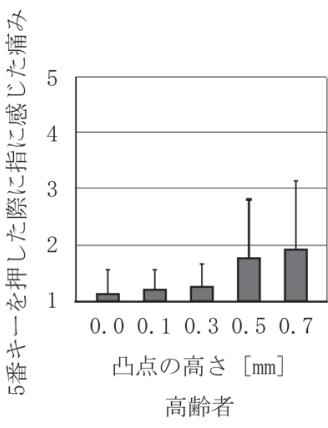

（c）5番キーを押した際に指に感じた痛み

$*: \mathrm{p}<0.05, * *: \mathrm{p}<0.01, * * * \mathrm{p}<0.001$

図 5 人差し指による実験の主観評価の結果
（3）操作の確信度

図 5(a) より, 若年者では, $0.0[\mathrm{~mm}]$ と $0.1[\mathrm{~mm}]$, $0.1[\mathrm{~mm}]$ と $0.3[\mathrm{~mm}], 0.5[\mathrm{~mm}]$ と $0.7[\mathrm{~mm}]$ の各 条件間を比較すると，それぞれ高さが低い条件では， 操作の確信度が有意に低かった $(\mathrm{p}<0.05)$. 高齢 者では, $0.1[\mathrm{~mm}]$ に比べて $0.0[\mathrm{~mm}], 0.3[\mathrm{~mm}]$ に 比べて $0.1[\mathrm{~mm}]$ は確信度が有意に低かった（p< 0.05)，若年者と高齢者ともに，凸点が高いほど操 作の確信度が高かった。

（4） 5 番キーの発見しやすさ

図 5(b)より, 若年者では, $0.0[\mathrm{~mm}]$ と $0.1[\mathrm{~mm}]$, $0.1[\mathrm{~mm}]$ と $0.3[\mathrm{~mm}], 0.3[\mathrm{~mm}]$ と $0.5[\mathrm{~mm}]$ の 各 条件間を比較すると，それぞれ高さが低い条件では， 5 番キーが有意に発見しにくかった $(\mathrm{p}<0.05)$ ，高 齢者では, $0.1[\mathrm{~mm}]$ は $0.3[\mathrm{~mm}]$ と比較して, 5 番 キーが有意に発見しにくかった $(\mathrm{p}<0.001)$. 若年 者と高齢者のいずれも，凸点が高いほど 5 番キーの 位置が発見しやすかった。

（5）5番キーを押した際に指に感じた痛み

図 5(c) より，若年者では， $0.3[\mathrm{~mm}]$ に対して $0.5[\mathrm{~mm}]$, さらに $0.5[\mathrm{~mm}]$ に対して $0.7[\mathrm{~mm}]$ は, 人差し指に感じる痛みが有意に大きかった（ $\mathrm{p}<$ 0.001). 高齢者では, 条件間で有意な差は認められ なかった。一方，若年者と高齢者ともに，凸点が高 いほど強い痛みを感じた。しかし, 最も強く痛みを 感じた $0.7[\mathrm{~mm}]$ の高さにおいても, 若年者及び高 齢者の痛みのスコアは 3 に満たず，強い痛みを感じ なかった

（6）人差し指による両手操作の結果のまとめ

若年者では, $0.0[\mathrm{~mm}]$ から $0.3[\mathrm{~mm}]$ までの条件 間において，凸点が低い条件ほど操作時間が有意に 長かった $(\mathrm{p}<0.05)$. 0.3 [mm]以上の条件間では, 操作時間に有意な差は認められなかった。また, $0.1[\mathrm{~mm}]$ と比べて $0.0[\mathrm{~mm}]$ はエラー率が有意に高 かった $(\mathrm{p}<0.05)$ ０.1[mm]以上の条件間では, エラー率に有意差は認められなかった。主観評価で は, 凸点が高いほど, 操作の確信度が高く，5番キ 一の位置が発見しやすかった，更に，5番キーを押 した時の痛みも増加したが, 最も痛みを感じた条件 に拈いても，強い痛みは感じなかった。 
（9）操作の仕方と凸点の高さが携帯電話の操作性に及ぼす影響の関係 109

高齢者では, $0.1[\mathrm{~mm}]$ は $0.3[\mathrm{~mm}]$ と比べて操作 時間が有意に長く, $0.0[\mathrm{~mm}]$ は $0.3[\mathrm{~mm}]$ と比べて エラー率が高かった $(\mathrm{p}<0.05) .0 .3[\mathrm{~mm}]$ 以上の 条件では，操作時間及びエラー率に有意な差は認め られなかった，主観評価では，凸点が高いほど，操 作の確信度が高く， 5 番キーの位置が発見しやすか った。更に， 5 番キーを押した時の痛みも増加した が, 最も痛みを感じた条件においても，痛みはあま り感じなかった。

以上の通り, 人差し指による両手操作では, 若年 者と高齢者のいずれにおいても，凸点が $0.3[\mathrm{~mm}]$ 以上の高さは, 高さ $0.1[\mathrm{~mm}]$ と比べて操作時間が 短く、エラー率が低かった。また, 若年者と高齢者 ともに, 高さ $0.3[\mathrm{~mm}]$ 以上の条件間では, 操作時 間とエラー率に有意差が認められなかった。また, 凸点が高いほど，主観的に操作しやすかった。

\section{2 人差し指と親指による操作の比較}

本項では, 3.1 節で述べた本研究において新たに 実施した人差し指による両手操作の結果と, 先行研 究9)において実施した親指による片手操作の結果を 比較し、それらの違いに関して評価する。なお，親 指による実験では，晴眼若年者 20 名（平均年齢 $21.6 \pm 1.5$ 歳) 及び晴眼高齢者 20 名（平均年齢 $67.5 \pm 4.0$ 歳) が参加した。実験方法は, 本研究に おける人差し指による操作実験と同様であった。

人差し指と親指の各操作実験の結果として, 図 6 （a）（b）に操作時間，図 7(a)（b）にエラー率を示 す。親指に扔ける操作においては，若年者では 0.3 $[\mathrm{mm}]$ に対して $0.7[\mathrm{~mm}]$ は，有意に操作時間が長 くエラー率が高かった $(\mathrm{p}<0.001)$ ．また，高齢者 においても，0.3[mm]よりも凸点が高くなるにつ れて, 操作時間とエラー率がわずかに増加した。こ うした結果は，3.1節で述べた人差し指による結果 とは異なる. 即ち, 人差し指による両手操作では, 若年者及び高齢者のいずれにおいても，凸点が 0.3 $[\mathrm{mm}]$ 以上の高さ間で操作時間とエラー率の有意差 は認められず, 親指による片手操作の結果で認めら れたような凸点の高さの増加に伴う操作時間やエラ 一率の増加は確認されなかった。
以上の通り，凸点の高さが $0.3[\mathrm{~mm}]$ よりも高い 条件に扔いては, 人差し指と親指の操作する指の違 いに応じて, 凸点の高さによる操作性への影響が異 なることが明らかとなった。

\section{4. 考察}

人差し指による実験の結果より, 若年者と高齢者 のいずれにおいても，携帯電話の 5 番キーに凸点が 付されていない場合に比べて, 高さ $0.3[\mathrm{~mm}]$ の凸 点が付されていると, 操作時間が短くエラー率が低 いことが明らかとなった。これは, 先行研究9)で行 った親指による片手操作の結果と同様である（図 6 及び図 7 参照)。これらは, 凸点が操作上のランド マークとして機能したことで, テンキーの位置関係 を速く正確に把握できたからだと考えられる。この ように, 5 番キーに付された凸点は, 親指と人差し 指のいずれの操作においても, 携带電話の操作性を 向上させる有効な触覚サインであることが明らかと
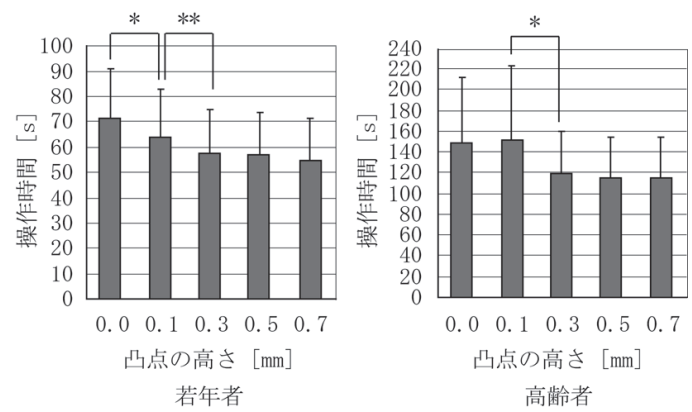

（a）人差し指による操作時間の結果
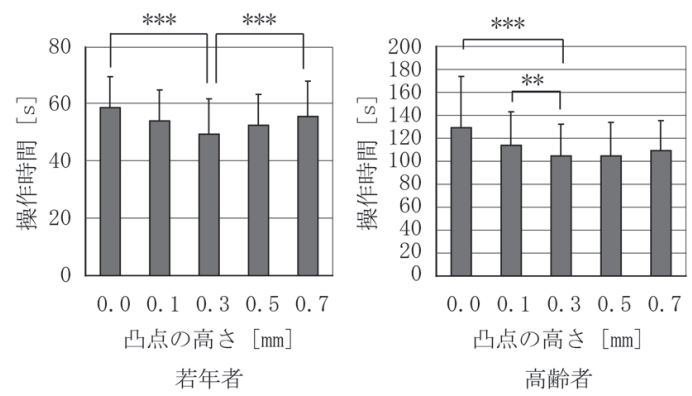

(b) 親指による操作時間の結果 9$)$

$*$ : p < 0.05, **: p <0.01, ***: p < 0.001

図 6 人差し指及び親指による操作時間の結果 
なった。

続いて, 携帯電話の操作性の向上に適する凸点の 高さの条件に関して述べる。 人差し指の操作実験に おいて, 高さ $0.1[\mathrm{~mm}]$ は $0.3[\mathrm{~mm}]$ 以上の条件と比 ベて, 若年者と高齢者ともに操作時間が有意に長か った。また，高齢者においてはエラー率が高かった (図 4 参照)。また，筆者らが実験中に参加者の指の 動きを目視で観察したところ, 高さ $0.1[\mathrm{~mm}]$ の凸 点が付されている場合に, 全ての参加者において, 凸点に触れているのにもかかわらず，凸点を何度も 指先で触れて探すような指の挙動が確認できた。こ うした指の挙動は, 高さ $0.3[\mathrm{~mm}]$ 以上の凸点が付 されている場合には, 確認できなかった。これらは 親指による実験においても同様に確認された，以上 のことから, 高さ $0.1[\mathrm{~mm}]$ の凸点は, ヒトの指先 に打ける触覚特性上, 携帯電話の操作中には容易に 触知することができないと考えられる。市場で流通 する携帯電話のテンキーの形状やレイアウトは様々 であるが，本実験で使用した機種とは異なる携带電 話に凸点を付す際においても，高さ $0.1[\mathrm{~mm}]$ の凸
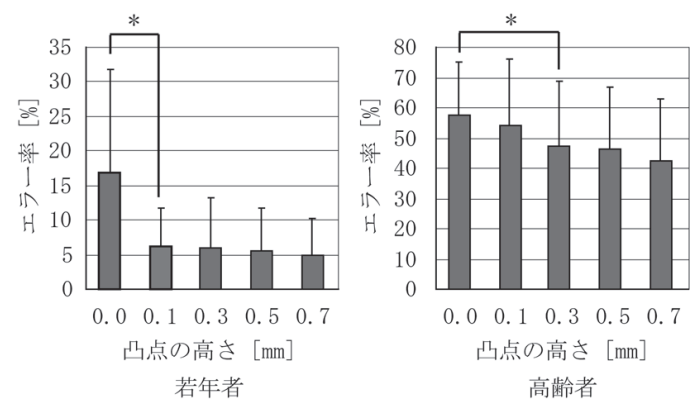

（a）人差し指によるエラー率の結果
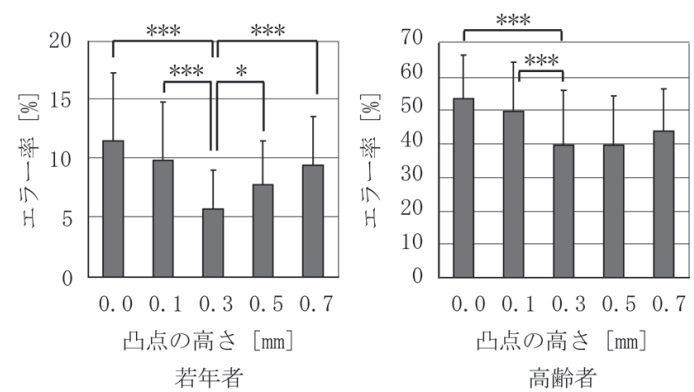

(b) 親指によるエラー率の結果 9 )

$*: \mathrm{p}<0.05, * *: \mathrm{p}<0.01, * * *: \mathrm{p}<0.001$

図 7 人差し指及び親指によるエラー率の結果
点は操作中に触知しづらくランドマークとしては機 能しにくいと考えられ，携带電話に付す凸点の高さ としては適さない寸法である.

他方, 親指による片手操作では, 凸点が $0.3[\mathrm{~mm}]$ よりも高くなるにつれ，若年者及び高齢者ともに操 作時間及びエラー率が増加した。しかし，人差し指 による両手操作では，そのような結果は認められな かった（図 6 及び図 7 参照）。これは，各指の操作 に打ける手指の動作の違いに起因すると推察される。 筆者らが実験中に参加者の指の挙動を目視で観察し たところ，0.3[mm]よりも大きい凸点が付されて いると, 親指と人差し指のいずれの操作においても 操作を行う指が凸点の上を通過する際に，操作する 指と凸点が衝突しないようにテンキーから指を離す 様子が確認できた，とりわけ，高さ $0.7[\mathrm{~mm}]$ の 点において，顕著に確認された。このように，高い 凸点が付されていると指先の回避動作が必要となる と考えられるが，人差し指による両手操作は，片手 による親指の操作と比べ，こうした回避動作が容易 に行えると考えられる。即ち，人差し指による両手 操作では，片手で携帯電話を保持しながら，もう片 方の手で操作を行うため（図 $1(\mathrm{a})$ )，各手が分業し て異なるタスクを行うことができるため，操作を行 う側の手指の動作を凸点の高さに応じて適切に調節 することが可能であると考えられる。そのため，人 差し指による両手操作では, 凸点が高い場合におい ても，操作性の低下が認められなかったと考えられ る. 一方, 親指による片手操作では, 親指によるテ ンキーの操作と, その他の指による携帯電話の保持 という 2 つの動作を同時に行わなければならない (図 1(b) 参照)。このような操作姿勢では，高い凸 点を避けるように親指を動かそうとすると, 安定し た携帯電話の保持に支障が生じると考えられる。 そ のため, 凸点が高いほど指先の動作が制限されて早 く正確に操作することができなくなり，操作エラー が引き起こされる可能性があるとも考えられる。と りわけ，親指が凸点の上を跨いで次のキーを入力す る場合に，最も手指の自由な動きが制限されるため, 操作エラーが増加すると推察される.

以上の通り，携帯電話の操作性向上に適う凸点の 
（9）操作の仕方と凸点の高さが携帯電話の操作性に及ぼす影響の関係 111

高さは，操作を行う手指によって異なる，具体的に は，親指による片手操作と人差し指による両手操作 では, いずれも高さ $0.3[\mathrm{~mm}]$ が早く正確に操作で きたが，親指による片手操作では，高さ $0.3[\mathrm{~mm}]$ 以上に抏いて，操作時間とエラー率ともに増加した。 この知見から, 携帯電話の 5 番キーに凸点を付す際 には，凸点の高さを $0.3[\mathrm{~mm}]$ とすることで，親指 による片手及び人差し指による両手操作を行う各一 般ユーザーにおいて，特に操作性が向上すると考え られる。また，ユーザーへの配慮として，企業が凸 点を携帯電話に付す場合に，その製品のユーザーが 人差し指による両手操作を行うことが特に想定でき るならば, 高さ $0.3[\mathrm{~mm}]$ 以上の凸点を付すことも 有用であると考えられる。

\section{5. 結論}

本研究では, 携帯電話の操作の仕方として人差し 指による両手操作と親指による片手操作に着目し, これらの操作の仕方と凸点の高さが携帯電話の操作 性に及ぼす影響の関係を評価することを目的とした。 本実験では, 中途失明の一般ユーザーを想定して, 手元を遮蔽した参加者に 5 番キー中央に高さが異な る凸点が付された携帯電話を，両手人差し指を用い て操作させる実験を行った。更に, 先行研究9)にお ける親指による片手操作の結果と比較することで, 各操作の仕方に扔ける凸点の高さが携帯電話の操作 性に及ぼす影響の違いを評価した。その結果，親指 による片手操作と人差し指による両手操作のいずれ も，年齢の属性にかかわらず，高さ $0.3[\mathrm{~mm}]$ が早 く正確に操作できた。一方, 親指による片手操作で は, 高さ $0.3[\mathrm{~mm}]$ よりも高くなると, 操作時間と エラー率ともに増加したが, 人差し指による両手操 作では, そのような操作時間とエラー率の増加が見 られなかった。携帯電話を親指で操作するユーザー を考慮すると, 携帯電話に付す凸点の高さとしては, $0.3[\mathrm{~mm}]$ が望ましいと考えられる。なお，各操作 の仕方による凸点の適切な高さの違いは, 各操作に おける手指の動作の違いに起因すると考えられる。 以上の通り, 本研究により, 操作の仕方と凸点の高 さが携帯電話の操作性に及ぼす影響の関係が明らか となった。

\section{謝辞}

本研究の実施にあたって, 日本学術振興会科研費 補助金（基盤 B NO. 22300202）の援助を受けた. ここに感謝の意を表す.

\section{参考文献}

1）財団法人日本規格協会：JIS Z 8071(高齢者及び障害の ある人々のニーズに対応した規格作成配慮指針), 財団 法人日本規格協会, (2003).

2）財団法人日本規格協会：JIS T0921(高齢者・障害者配慮 設計指針一点字の表示原則及び点字表示方法一公共施 設・設備), 財団法人日本規格協会, (2006).

3）財団法人日本規格協会：JIS T0922（高齢者・障害者配慮 設計指針一触知案内図の情報内容及び形状並びにその表 示方法，，財団法人日本規格協会，（2007）.

4) International Organization for Standardization: ISO/ IEC Guide 71 (Guidelines for standards developers to address the needs of older persons and persons with disabilities), International Organization for Standardization, (2001).

5）財団法人日本規格協会：JIS S 0011 (高齢者・障害者配 慮設計指針一消費生活製品の凸記号表示)，財団法人日 本規格協会, (2000).

6）財団法人家電製品協会：『凸記号モニター調査』報告書 (平成 11 年度), 財団法人家電製品協会, (2000).

7）星川安之：ISO/TC173に発足した新 SC アクセシブル デザインへの経緯，日本生活支援工学会誌，10(1)，3-8， (2010).

8）星川安之, 佐川賢：より多くの人が使いやすいアクセシ ブルデザイン大門, 56-59, 財団法人日本規格協会, (2007).

9）豊田航，土井幸輝，藤本浩志：凸点の高さが携帯電話の 操作性に及ぼす影響に関する研究, 日本機械学会論文集 C 編，76(763)，690-695，(2010).

10）大河内直之, 前田晃秀, 布川清彦, 中野泰志, 松丸久美 子, 茠田知則, 中野聡子, 福島智, 松岡政治, 大成直子, 竹中和正, 豊田興太郎：携帯電話 - PHS の利用実態に 関するアンケート調査一全盲と大学生・専門学校生の比 較一. 第 13 回視覚障害リハビリテーション研究発表大 会論文集，13，86-89，(2004）。 


\title{
Relationship between Input Methods and the Influence of the Height of Tactile Dots on Input Performance when Operating Cellular Phones
}

\author{
Wataru TOYODA ${ }^{1}$, Kouki DOI $^{2}$, Hiroshi FUJIMOTO ${ }^{1}$ \\ ${ }^{1}$ Waseda University, ${ }^{2}$ National Institute of Special Needs Education
}

\begin{abstract}
In 2000, Japanese Standards Association standardized tactile dots and bars on consumer products for all people, including older people and people with disabilities. However, the numerical values for the size of tactile dots and bars were not determined on the basis of reliable data. The purpose of this study is to evaluate the relationship between input methods (the two-handed forefinger input and the one-handed thumb input) and the influence of the height of tactile dots (i.e., 0.0, 0.1, 0.3, 0.5 , and $0.7 \mathrm{~mm}$ ) on input performance when operating cellular phones. To analyze the influence of the height of tactile dots for each input method, we compared the results for the two-handed forefinger method from this study and that for the one-handed thumb method from our previous study. Normal sighted young and old participants, whose hands were covered by a curtain, operated cellular phones with a tactile dot on key 5 and other phones without a tactile dot. They operated the numerical keypad with the forefinger or the thumb while looking at 50 randomly ordered Arabic numbers one at a time. As a result of the experiments, both group of participants performed better with a tactile dot, rather than without it, using each input method, and they could operate more accurately and quickly especially in the case of a $0.3 \mathrm{~mm}$ high dot. On the other hand, by using the one-handed thumb method, the input performance deteriorated when the tactile dot was higher than $0.3 \mathrm{~mm}$. However, by using the twohanded forefinger method, the input performance did not deteriorate as the height of the tactile dot was increased. This result was attributed to the differences in operating characteristics between one-handed and two-handed input methods.
\end{abstract}

Key Words: Tactile Dot, Accessible Design, Operational Performance, Cellular Phone, Standard 